\title{
Life table studies of three mango hopper species in field conditions
}

\author{
Raja Riaz Hassan Awan ${ }^{1}$, Abdul Ghani Lanjar ${ }^{2}$, Aslam Bukero ${ }^{3}$, Imtiaz \\ Ahmed Nizamani $^{2}$, Shahzad Ali Nahiyoon ${ }^{3 *}$ and Dileep Kumar ${ }^{4}$ \\ 1. Department of Agriculture Extension, Government of Sindh, Pakistan \\ 2. Department of Plant Protection, Sindh Agriculture University, Tandojam, Sindh, Pakistan \\ 3. Department of Entomology, Sindh Agriculture University, Tandojam, Sindh, Pakistan \\ 4. Institute of Food Sciences \& Technology, Sindh Agriculture University, Tandojam, Sindh, Pakistan \\ *Corresponding author's email: sanahiyoon@sau.edu.pk \\ Citation
}

Raja Riaz Hassan Awan, Abdul Ghani Lanjar, Aslam Bukero, Imtiaz Ahmed Nizamani, Shahzad Ali Nahiyoon and Dileep Kumar. Life table studies of three mango hopper species in field conditions. Pure and Applied Biology. Vol. 11, Issue 1, pp284-290. http://dx.doi.org/10.19045/bspab.2022.110030

\begin{tabular}{llll}
\hline \hline Received: 20/04/2021 & Revised: 19/06/2021 & Accepted: 24/06/2021 & Online First: 29/06/2021 \\
\hline
\end{tabular}

\section{Abstract}

Mango is a fruit-producing tropical tree belonging to the flowering plant genus Mangifera, cultivated mostly for their edible fruit. Most of these species are found in nature as wild mangoes. The present study was conducted in the Horticultural Garden, Sindh Agriculture University, Tandojam, Pakistan. Life table studies revealed that the surviving fraction ( $\mathrm{Sx}$ ) in the egg stage of Amritodus atkinsoni, Idioscopus clypealis, and Idioscopus niveosparsus, was calculated as 0.94, 0.95, and 0.97; Mortality survival ratio (MSR) were 0.07, 0.05, and 0.04 and Indispensable mortality (IM) were 65, 49 and 35 . Similarly, the Sx in nymphs of all three hopper species were calculated as $0.942,0.954$, and 0.964 ; MSR were $0.062,0.048$, and 0.036 and IM were 48.8, 39.8, and 31.0, respectively. The k-value from egg to $5^{\text {th }}$ instar nymph of A. atkinsoni ranged (0.01-0.03), I. clypealis (0.02-0.03), and I. niveosparsus $(0.01-0.02)$. It is concluded that mortality, apparent mortality, mortality, survival ratio, and indispensable mortality were highest in egg, $3^{\text {rd, }}$ and $4^{\text {th }}$ instars of I. clypealis. However, the maximum $\mathrm{K}$-value was recorded among egg, $3^{\text {rd }}$, and $4^{\text {th }}$ instars, respectively. In the case of $A$. atkinsoni with a variation in $\mathrm{k}$ - value that was maximum in $3^{\text {rd }}$ and $4^{\text {th }}$ instars. Life table studies of I. neviosparsus revealed that maximum apparent mortality, survival fraction ratio, and indispensable mortality were noted in the $4^{\text {th }}$ instar. Whereas the maximum k-value was recorded in egg, $3^{\text {rd }}, 4^{\text {th }}$, and $5^{\text {th }}$ instar nymphs. The total K-value was highest in the case of I. clypealis followed by A. atkinsoni and $I$. neviosparsus, respectively.

Keywords: Amritodus atkinsoni; Idioscopus clypealis, Idioscopus niveosparsus; Life table

\section{Introduction}

Mango (Mangifera indica L) most delicious fruit in the world. This fruit is the most favored of the subcontinent and designated as king of all fruits. It is ranked as mostly due to its better flavor, pleasant taste, and possess massive nutritional worth, containing vitamins $\mathrm{A}$ and $\mathrm{C}$. It has been cultivated in South Asia for the last four thousand years [1]. Presently this fruit is commercially grown in the subtropical regions mainly Pakistan, India, and Bangladesh. The Asian countries contribute $77 \%$, Americas and African shares for 13 and $9 \%$, in mango production, respectively [2]. Therefore, mango production is adversely affected when insect species cause damage from nursery raising to its harvesting. Nearly three hundred plant feeder's insects have been recorded to ravage the mango orchard in different areas of the world [3]. Amongst these insect pests about more than twelve species are considered major insect pests, which are responsible to cause heavy yield loss in mango fruit [4]. Tara et al. [5] 
reported that mango plants are adversely affected by various sucking insects. The majority of mango hoppers species like $I$. clypealis, A. atkinsoni, and I. neviosparsus are considered major insect pests. Both nymphs and adults of mango hoppers damage to new flushes, leaves, and inflorescences of mango plants [6-8]. Patel et al. [3] reported that nymphs and adults of the hoppers making a pinhole in the tender shoots, inflorescences, and leaves suck the sap from it, which causes the absence of flower-bearing and falling of immature fruits, and cause a reduction in yield. Hoppers were also responsible to promote sooty molds, that cause fungal disease on the lower side of leaves, branches, and fruits in moist weather. Within few days of the attack, the whole leaf becomes blackish that restricts the photosynthetic movement in plants. This injury is denoted as a honeydew disease. More than $50 \%$ of crop losses have been recorded due to severely infested trees. Mango hopper species (I. clypealis, I. niveosparsus and A. atkinsoni) have great impact due to their long-term flight on panicles and leaves, respectively [9]. Similarly, [7] observed both $A$. atkhinsoni and I. niveosparsus on the upper portions of mango trees at different times of the year. Mango hoppers were settled on the crop during the vegetative and reproductive phases. The highest occurrence was observed during the blossom phase of the crop after which the insects traveled to cracks and crevices of the trunk [10]. Various studies were conducted by Anitha et al. [11] on the impact of abiotic factors on the occurrence of the hopper and its management practices by using agro-chemicals in the mango field. However, there is a basic need to conduct a comprehensive study to determine the impact of environmental factors on different life stages of mango hoppers.

\section{Materials and methods}

This research was carried out in Horticultural Garden, Sindh Agriculture University, Tandojam. Three years old mango plants were brought into the field and planted in the pits prepared, during its flowering stage to record the life table of the mango hopper. For this purpose, newly hatched (1000) eggs of each of three mango hopper spp. were kept separately on inflorescence. Then mango plant was caged into a wooden frame of five feet width and five feet height which was covered with a green muslin cloth to prevent the in and out movement of any living organism, it was done to just decrease the error in data to be recorded throughout the observation period. Thereafter, the observations were recorded on several surviving eggs, nymphs, and adults of mango leafhopper carefully with the help of magnifying glasses, camel brush, and Ariel net. The life table was constructed according to the formula described by [12].

$\mathrm{x}=$ Stage of the insect

$1 \mathrm{x}=$ Number surviving at the beginning of the stage $\mathrm{x}$

$\mathrm{dx}=$ Mortality during the stage indicated in the column $\mathrm{x}$

100qx= Apparent mortality

$\mathrm{Sx}=$ Survival fraction

$\mathrm{MSR}=$ Mortality survival ratio

$\mathrm{IM}=$ Indispensable mortality

$\mathrm{Lx}=\log$

$\mathrm{K}$-value $=$ Killing value

The data calculated through the above assumptions were used for computing various life parameters as given below:

\section{Apparent mortality (100q)}

It gives the information on $\mathbf{x}$ number dying as a percentage of number entering that stage and was calculated by using the formula;

Apparent Mortality $=[\mathrm{d} / \mathrm{l}] \times \mathbf{1 0 0 S u r v i v a l}$ Fraction $(\mathrm{Sx})$

The data obtained on apparent mortality was used for the calculation of the stagespecific survival fraction $(\mathrm{Sx})$ of each stage by using the equation;

Sx of particular stage $=[\mathrm{lx}$ of subsequent stage $] /[\mathrm{lx}$ of particular stage]

\section{Mortality survivor ratio (MSR)}

It is the increase in population that would 
have occurred if the mortality in the stage, in question had not occurred and was calculated as follows;

MSR of particular stage $=[$ Mortality in particular stage $] /[\mathrm{lx}$ of subsequent stage]

\section{Indispensable mortality (IM)}

This type of mortality would not be there in case the factor (s) causing it is not allowed to operate. However, the subsequent mortality factors operate. The equation is;

IM $=[$ Number of adults emerged $] \times$ [M.S.R. of particular stage]

\section{K-values}

It is the key factor, which is primarily responsible for increase or decrease in number from one generation to another and was computed as the difference between the successive values for $" \log l_{x}$ ". However, the $\mathrm{x}$ total generation mortality was calculated by adding the $\mathrm{k}$ values of different development stages of the insect, which is designated/ indicated as " $\mathrm{K}$ " [13, 14].

$\mathrm{K}=\mathrm{kE}+\mathrm{kN} 1+\mathrm{kN} 2+\mathrm{kN} 3+\mathrm{kN} 4+\mathrm{k} \mathrm{N} 5$

Where, $\mathrm{kE}+\mathrm{kN} 1+\mathrm{kN} 2+\mathrm{kN} 3+\mathrm{kN} 4$ and $\mathrm{k}$ N5 are the k-values at the egg and nymphal stages of $1^{\text {st }}, 2^{\text {nd }}, 3^{\text {rd }}, 4^{\text {th, }}$ and $5^{\text {th }}$ instar of mango hoppers.

\section{Results and discussion}

The results presented in (Table 1). indicated the stage-specific life table experiments of mango hopper species, under field conditions. The following results were achieved after the completion of observations.

\section{Surviving fraction $(\mathbf{S x})$}

The outcome described in (Table 1). initiated that survival fraction in maximum counts was $0.94 \mathrm{I}$. clypealis while the maximum counts for A. atkinsoni for same were 0.95 whereas the maximum figure in this regard pertained with I. neviosparsus was also observed that uppermost Survival fraction $(\mathrm{Sx})$ was calculated 0.98 in first instar of $I$. neviosparsus, whereas $A$. atkinsoni had 0.97 and I. clypealis 0.96 during $1^{\text {st }}$ instar. In the same way highest survival fraction for $2^{\text {nd }}$ moulting period was 0.97 for $A$. atkinsoni and 0.96 for $I$. neviosparsus but the counts were distinct for I. clypealis which were 0.95 . The $3^{\text {rd }}$ instar observation revealed that maximum survival fraction recorded I. neviosparsus 0.96 A. atkinsoni 0.94 and I. clypealis 0.93 after the completion of $3^{\text {rd }}$ instar insect stepped in $4^{\text {th }}$ instar in this instar the peak survival fraction recorded for mango hopper species was I. neviosparsus $0.94 \mathrm{~A}$. atkinsoni 0.93 and I. clypealis 0.93 . In this way, the $5^{\text {th }}$ instar maximum survival fraction calculation was $I$. neviosparsus 0.95 A. atkinsoni 0.94 and I. clypealis 0.94 . Hence it was observed that the maximum survival fraction was noted for mango hopper species $I$. neviosparsus during $1^{\text {st }}$, $3^{\text {rd }}, 4^{\text {th, }}$ and $5^{\text {th }}$ instar while the highest survival fraction during $2^{\text {nd }}$ instar was recorded in $A$. atkinsoni. Whereas the lowest population of survival fraction was recorded in I. clypealis during $1^{\text {st }}, 2^{\text {nd, }}$ and $3^{\text {rd }}$ instar while the $4^{\text {th }}$ and $5^{\text {th }}$

atkinsoni and I. clypealis which was 0.93 .

\section{Apparent motility (100 qx)}

Peak outcome of apparent mortality for egg stage of the hopper was recorded in $I$. clypealis which was $6.5 \%$ followed by $A$. atkinsoni $4.9 \%$ and I. neviosparsus $3.5 \%$ mortality. For the period of $1^{\text {st }}$ instar the maximum mortality calculated in $I$. clypealis was $3.85 \%$ while the lowest record was for A. atkinsoni $3.26 \%$ and $I$. neviosparsus $2.18 \%$ mortality. Apparent mortality for $2^{\text {nd }}$ instar calculation revealed that maximum mortality has occurred in $I$. clypealis $5.01 \%$ although lowest mortality counts were $3.92 \%$ In I. neviosparsus and death percentage for A. atkinsoni in this instar was $3.04 \% .3^{\text {rd }}$ instar mortality peak was recorded at $7.26 \%$ in I. clypealis followed by $5.61 \%$ in A. atkinsoni and 3.64 $\%$ in I. neviosparsus. The same procedure for mortality counts also continued during the $4^{\text {th }}$ instar, the maximum mortality percentage for this instar was $7.45 \%$ in $I$. clypealis, while the lowest mortality recorded was $7.13 \%$ in A. atkinsoni followed by $5.48 \%$ in I. neviosparsus. 
Highest mortality in the $5^{\text {th }}$ instar was calculated in $5.73 \%$ I. clypealis followed by $A$. atkinsoni $5.63 \%$ and I. neviosparsus $5.10 \%$. These results revealed that the highest mortality percentage throughout the observation was in I. clypealis, which happened in all instars. Although the lowest mortality percentage during $1^{\text {st }}, 3^{\text {rd }}, 4^{\text {th }}$ and $5^{\text {th }}$ instar was counted in I. neviosparsus whereas the minimum mortality percentage for $2^{\text {nd }}$ instar was recorded in A. atkinsoni.

Table 1. Life table of mango hopper species on inflorescences of the mango plant in field conditions

\begin{tabular}{|c|c|c|c|c|c|c|c|c|}
\hline $\begin{array}{c}\text { Stage } \\
(\mathbf{x})\end{array}$ & $\begin{array}{l}\text { No. surviving } \\
\text { at the } \\
\text { beginning of } \\
\text { stage (lx) }\end{array}$ & $\begin{array}{l}\text { No. dying } \\
\text { in each } \\
\text { stage }(d x)\end{array}$ & $\begin{array}{c}\text { Apparen } \\
\mathbf{t} \\
\text { mortality } \\
(100 q x)\end{array}$ & $\begin{array}{l}\text { Survival } \\
\text { fraction } \\
\text { (Sx) }\end{array}$ & $\begin{array}{c}\text { Mortality } \\
\text { survivor } \\
\text { ratio } \\
\text { (MSR) }\end{array}$ & $\begin{array}{c}\text { Indispensa } \\
\text { ble } \\
\text { mortality } \\
\text { (IM) }\end{array}$ & $\begin{array}{c}\log \\
\text { (lx) }\end{array}$ & $\begin{array}{c}\text { k- } \\
\text { Value }\end{array}$ \\
\hline \multicolumn{9}{|c|}{ Idioscopus clypealis } \\
\hline Eggs & 1000 & 65 & 6.50 & 0.94 & 0.07 & 65.00 & 3.00 & 0.03 \\
\hline $1^{\text {st }}$ instar & 935 & 36 & 3.85 & 0.96 & 0.04 & 36.00 & 2.97 & 0.02 \\
\hline $2^{\text {nd }}$ instar & 899 & 45 & 5.01 & 0.95 & 0.05 & 45.00 & 2.95 & 0.02 \\
\hline $3^{\text {rd }}$ instar & 854 & 62 & 7.26 & 0.93 & 0.08 & 62.00 & 2.93 & 0.03 \\
\hline $4^{\text {th }}$ instar & 792 & 59 & 7.45 & 0.93 & 0.08 & 59.00 & 2.90 & 0.03 \\
\hline $5^{\text {th }}$ instar & 733 & 42 & 5.73 & 0.94 & 0.06 & 42.00 & 2.87 & 0.03 \\
\hline Adults & 691 & 691 & 100.00 & & & & 2.84 & \\
\hline & & & & & & & & 0.16 \\
\hline \multicolumn{9}{|c|}{ Amritodus atkinsoni } \\
\hline Egg & 1000 & 49 & 4.90 & 0.95 & 0.05 & 49.00 & 3.00 & 0.02 \\
\hline $1^{\text {st }}$ instar & 951 & 31 & 3.26 & 0.97 & 0.03 & 31.00 & 2.98 & 0.01 \\
\hline $2^{\text {nd }}$ instar & 920 & 28 & 3.04 & 0.97 & 0.03 & 28.00 & 2.96 & 0.01 \\
\hline $3^{\text {rd }}$ instar & 892 & 50 & 5.61 & 0.94 & 0.06 & 50.00 & 2.95 & 0.03 \\
\hline $4^{\text {th }}$ instar & 842 & 53 & 6.29 & 0.94 & 0.07 & 53.00 & 2.93 & 0.03 \\
\hline $5^{\text {th }}$ instar & 789 & 37 & 4.69 & 0.95 & 0.05 & 37.00 & 2.90 & 0.02 \\
\hline Adults & 752 & 738 & 98.14 & & & & 2.88 & \\
\hline & & & & & & & & 0.12 \\
\hline \multicolumn{9}{|c|}{ Idioscopus niveosparsus } \\
\hline Eggs & 1000 & 35 & 3.50 & 0.97 & 0.04 & 35.00 & 3.00 & 0.02 \\
\hline $1^{\text {st }}$ instar & 965 & 21 & 2.18 & 0.98 & 0.02 & 21.00 & 2.98 & 0.01 \\
\hline $2^{\text {nd }}$ instar & 944 & 24 & 2.54 & 0.97 & 0.03 & 24.00 & 2.97 & 0.01 \\
\hline $3^{\text {rd }}$ instar & 920 & 33 & 3.59 & 0.96 & 0.04 & 33.00 & 2.96 & 0.02 \\
\hline $4^{\text {th }}$ instar & 887 & 46 & 5.19 & 0.95 & 0.05 & 46.00 & 2.95 & 0.02 \\
\hline $5^{\text {th }}$ instar & 841 & 31 & 3.69 & 0.96 & 0.04 & 31.00 & 2.92 & 0.02 \\
\hline \multirow[t]{2}{*}{ Adults } & 810 & 781 & 96.42 & & & & 2.91 & \\
\hline & & & & & & & & 0.09 \\
\hline
\end{tabular}

\section{Mortality survival ratio (MSR)}

The given data in (Table 1). shows that the maximum mortality survival ratio of egg stage was found at 0.07 in hopper species $I$. clypealis whereas, the minimum mortality survival ratio was 0.05 calculated in $A$. atkinsoni and 0.04 calculated for $I$. neviosparsus. Data counts show that the highest MSR during $1^{\text {st }}$ instar stage of the hopper belongs to 0.04 in I. clypealis followed by $A$. atkinsoni (0.03) and $I$. neviosparsus $(0.02)$. Data revealed for $2^{\text {nd }}$ instar the maximum MSR was 0.05 for $I$. clypealis and the lowest was $I$. neviosparsus 0.04 and A. atkinsoni 0.03 . The Highest MSR during $3^{\text {rd }}$ instar of the mango hopper was found in A. atkinsoni 0.08 although the lowest MSR counts were 0.06 in 0.04 in $A$. atkinsoni and $I$. neviosparsus. Calculated data shows that $I$. 
clypealis and A. atkinsoni had the same MSR which was 0.08 while A. atkinsoni stands with the lowest MSR of 0.06. Just like the $4^{\text {th }}$ instar, the MSR recorded for the $5^{\text {th }}$ instar was the same for I. clypealis and A. atkinsoni which were counted as 0.06 while I. neviosparsus reported with the lowest MSR 0.05.

\section{Indispensable mortality (IM)}

While the recording of Indispensable mortality (IM) was observed which showed that the maximum (IM) in egg stage was (65) in I. clypealis the factor of mortality was infertility, whereas the same factor was recorded and calculated in A. atkinsoni which was (49) eggs, whereas the lowest number of eggs were (35) recorded in $I$. neviosparsus. The highest mortality during $1^{\text {st }}$ instar revealed (36) in I. clypealis, although it was less in A. atkinsoni with (31) nymphs the mortality for this stage counted (21) nymphs in I.neviosparsus.

Mortality during $2^{\text {nd }}$ nymphal instar indicated maximum numbers (45) in $I$. clypealis followed by (37) and (28) in I. neviosparsus and A. atkinsoni respectively. Peak numbers of mortality occurred throughout $3^{\text {rd }}$ nymphal stage was (62) for I. clypealis while the lower and lowest was recorded as (50) and (33) for A. atkinsoni and $I$. neviosparsus respectively. Mortality all over the $4^{\text {th }}$ molting stage was (60) in $A$. atkinsoni followed by I. clypealis (59) nymphs and minimum was (51) in $I$. neviosparsus. Mortality that occurred within the $5^{\text {th }}$ nymphal stage was highest in A. atkinsoni with (44) nymphs pursued by I. clypealis and I. neviosparsus with the same mortality was seen (42).

\section{k-value}

The result shows that the minimum $\mathrm{k}$-value during the egg stage was recorded at 0.02 in A. atkinsoni and I. neviosparsus, while the maximum was recorded in I. clypealis. 0.01 . Similarly, k-value was calculated as minimum during $1^{\text {st }}$ nymphal instar for it was once again $A$. atkinsoni as well $I$. neviosparsus whereas the highest was 0.02 pertained with $I$. clypealis. The $2^{\text {nd }}$ moulting stage revealed that maximum $\mathrm{k}$ - value was counted as in I. clypealis and $I$. neviosparsus while the lowest $\mathrm{k}$-value 0.01 was in A. atkinsoni. $3^{\text {rd }}$ instar described the lowest $\mathrm{k}$-value 0.02 of $A$. atkinsoni although the maximum was in both of the rest of mango hopper species. $0.03 \mathrm{k}$ - value was recorded for all of three mango hopper species throughout the $4^{\text {th }}$ immature stage. $5^{\text {th }}$ instar revealed that $A$. atkinsoni and $I$. clypealis both were with peak $\mathrm{k}$-value which was 0.03 but the k-value of $I$. neviosparsus was 0.02 which was lowest.

The outcome of the present investigation describes that the non-significant mortality and apparent mortality, mortality survival ratio, and indispensable mortality were highest in egg, $3^{\text {rd, }}$ and $4^{\text {th }}$ instars of $I$. clypealis whereas survival fraction was recorded non-significant for all life stages. However, maximum non- significant $\mathrm{K}$ value were recorded among egg, $3^{\text {rd }}$, and $4^{\text {th }}$ instars, respectively. Almost the same trend of life table data was recorded in the case of $A$. atkinsoni with a variation in $\mathrm{k}$ - value that was maximum in $3^{\text {rd }}$ and $4^{\text {th }}$ instars. Life table studies of $I$. neviosparsus revealed that maximum apparent mortality, survival fraction ratio, and indispensable mortality was note in the $4^{\text {th }}$ instar. Whereas non-significant maximum $\mathrm{k}$-value was recorded in egg, $3^{\text {rd }}, 4^{\text {th }}$, and $5^{\text {th }}$ instar nymphs. The total K-value was highest in the case of $I$. clypealis followed by $A$. atkinsoni and I. neviosparsus. Almost the same results were seen in the experiment conducted by various researchers. [15] revealed the same results during life table studies of cotton mealybug. They revealed that the highest killing rate was recorded in $1^{\text {st }}$ instar, whereas the maximum survivorship was seen in the $3^{\text {rd }}$ instars and pupae along with overall k-value (0.35). [16] examined at the highest MSR figures in the pre-pupal (0.04) and pupal stages $(0.06)$, whereas the lowest $(0.01)$ mortality was seen in the coccinellid species. Similarly, [17] described the overall " $K$ " in all subsequent stages were seen at maximum (0.2676) and minimum (0.1079) levels. [18] reported that the quality of host 
plant food influenced the fecundity of herbivorous insects were determined in the individual and the population scale. The nutritional quality of plants significantly influences insect survival, growth, and egglaying capacity [19]. Due to nutrient deficiency in host plants that adversely affected survival, body size, and development rate of the species. Whereas, the findings of [20] also endorsed to the [21] that population dynamics of plantfeeding insects can be significantly influenced by heterogeneousness in the quality of the plant. The natality and mortality of plant feeders were adversely affected by changing parameters that occur inside the plants such as survivor, growth, and fecundity. Similarly, [12] and [22] reported the highest death rate in Indian mustard followed by yellow Sarson, gobhi Sarson, and cauliflower in all life stages of $P$. brassicae due to an imbalance of the nutritional cycle of host plants. The highest survival fractions were observed at the immature stage of development on the cabbage as compared to other cole crops [23]. Shahjahan et al. [24] reported apparent mortality (100qx) was maximum (11.11) for pupa and minimum (5.00) was during $3^{\text {rd }}$ instar of Chrysoperla carnea fed on Planococcus citrimealy on the citrus plant.

\section{Conclusion}

It is concluded that mortality, apparent mortality, mortality, survival ratio, and indispensable mortality were highest in egg, $3^{\text {rd, }}$ and $4^{\text {th }}$ instars of I. clypealis. However, the maximum $\mathrm{K}$-value was recorded among egg, $3^{\text {rd }}$, and $4^{\text {th }}$ instars, respectively. In the case of $A$. atkinsoni with a variation in $\mathrm{k}$ - value that was maximum in $3^{\text {rd }}$ and $4^{\text {th }}$ instars. Life table studies of $I$. neviosparsus revealed that maximum apparent mortality, survival fraction ratio, and indispensable mortality was noted in the $4^{\text {th }}$ instar. Whereas the maximum $\mathrm{k}$-value was recorded in egg, $3^{\text {rd }}$, $4^{\text {th }}$, and $5^{\text {th }}$ instar nymphs. The total $\mathrm{K}$ value was highest in the case of I. clypealis followed by $A$. atkinsoni and $I$. neviosparsus, respectively.

\section{Author's contributions}

Conceived and designed the experiments: RRH Awan, Performed the experiments: RRH Awan \& AG Lanjar, Analyzed the data: RRH Awan, AG Lanjar \& A Bukero, contributed materials/ analysis/ tools: A Bukero \& IA Nizamani, Wrote the paper: RRH Awan \& A Bukero.

\section{Acknowledgment}

The authors are highly indebted to the Incharge of Horticultural Garden, Sindh Agriculture University Tandojam. We are also very thankful to the anonymous reviewers for their valuable suggestions which enabled us to present the refined version of this work.

\section{References}

1. Salunkhe DK and Desai BB (1994). Post- Harvest Technology of Fruits, vol. 1, CRC Press, Boca Raton, Fla, USA.

2. Pereira T, Tijskens LMM, Vanoli M, Rizzolo A, Eccherzerbini P, Torricelli A, Spinelli L \& Filgueiras H (2010). Assessing the harvest maturity of Brazilian mangoes. In EW Hevett (Eds) Proc IS on Post Harvest Pacifica 2013. Actara Horticulture, Pp. 880.

3. Patel JR, Shekh AM \& Ratanpara HC (2004). Seasonal incidence and effect of minimum temperature and vapour pressure on the population of mango hoppers in middle Gujarat. Gujrat Agri Uni Res Jr 20: 5-8.

4. Rajinder P \& Dhawan AK (2013). Integrated pest management. Innovation development processes 1 : 645.

5. Tara JS, Gupta M, Shrikhandia P, Bala A, Zaffar N \& Sharma S (2014). Record of some Hemipteran insect pests of mango (Mangifera indica) from Jammu region of Jammu and Kashmir State. Inter $J r$ Interdiscipl Multidiscipl Stud (IJIMS) 1(8): 19-29.

6. Das NM, Ramamany KS \& Nair MRGK (1969). Biology of a New Jassid of Mango Amrasca splendens Gauri. Ind Jr Ent 31(3): 288-290. 
7. Mohyuddin AI \& Mahmood R (1993). Integrated control of mango pests in Pakistan. Acta Hort 341: 467-483.

8. Varshneya A \& Rana KS (2013). Effect of abiotic factors on the population of mango leafhopper Amritodus atkinsoni (Leth.) (Hemiptera: Cicadellidae) in Western Uttar Pradesh, India. World Jr Appl Sci Res 3(2): 19-23.

9. Soomro A, Khuhro R \& Ansari $\mathrm{H}$ (1987). Status of insects associated with mango blossom. Proc $V$ Pak Congr Zool 5: 123- 125.

10. Babu LB, Maheshwari T \& Rao NV (2002). Seasonal incidence and biology of the mango hopper Amritodus atkinsoni (Homopetra: Cicadellidae). Entomon 27: 35-42.

11. Anitha KD, Lakshmi BKM, Reddy GS \& Lakshminarayana RM (2009). Influence of abiotic factors on the incidence of hopper and chemical control strategies in mango orchards. Karnataka Jr Agri Sci 22(3): 601- 602.

12. Ali A \& Rizvi PQ (2007). Age specific survival and fecundity table of Coccinella septempunctata L. (Coleoptera: Coccinellidae) on different aphid species. Ann Pl Pro Sci 15: 329-334.

13. Varley GC \& Gradwell GR (1960). Key factors in population studies. $J r$ Ani Eco 29: 399-401.

14. Southwood TRE (1978) Ecological methods with particular reference to study of insect population, The English Language Book Society and Chapman and Hall, London, pp: 524.

15. Sahito HA, Kousar T, Mangrio WM, Mallah NA, Jatoi FA, Shah ZH \& Kubar WA (2017). Stage specific life table of invasive pest mealybug, Phenacoccus solenopsis (Tinsley) under cotton field conditions. Curr Res Agri Sci 4(2): 43-50.

16. Rai RMK \& Singh PK (2002). Biological attributes and morphmetrics of Coccinella septempunctata (L.) (Coleoptera: Coccinellidae. Ann Pl Pro Sci 10: 194-197.

17. Omkar and Pervez A (2004). Temperature-dependant development and immature survival of an aphidophagous ladybeetle, Propylea dissecta (Mulsant). Jr App Ent 128: 510-514.

18. Awmack CS \& Leather SR (2002). Host plant quality and fecundity in herbivorous insects. Ann Rev Ent 47: 814-844.

19. Wheeler GS (2003). Melaleuca quinquenervia leaves of different nitrogen levels. Bio Cont 26: 109-116.

20. Sandra EHP (2005). Variation in plant quality and the dynamics of insect herbivore populations," M.Sc. Thesis Submitted to the Graduate Faculty of the University of Georgia.

21. Huberty AF (2005). Nutrient limitation and its consequences for phytophagous insects with divergent life-history strategies. Ph.D Thesis.

22. Rizvi SA, Neidt EM, Cui J, Feiger Z, Skau CT, Gardel ML, Kozmin SA \& Kovar DR (2009). Identification and characterization of a small molecule inhibitor of form in-mediated actin assembly. Chem \& Bio 16: 1158-1168.

23. Melspalu L, Hiiessar K, Joudie J \& Kuusik A (2003). Factor influencing the population number of large white butterfly, Pieris brassicae L. Sodininkyste Darzininkyste 22: 179185.

24. Shahjahan HJ, Khan AR, Saljoqi E, Shah HH, Khan I, Tasaddaq S, Ahmed I, Rasool A, Khan A \& Ali R (2020). Biological parameters and feeding efficiency of Chrysoperla carnea (Stephens) feed on Citrus mealy bug Planococcus citri under controlled conditions. Int Jr Agri Ext \& Soc Develop 3(1): 46-51. 